\title{
Impact of Microfinance on Socio-Economic Conditions of the Borrowers: A Case Study of Akhuwat Foundation (Lahore)
}

\author{
Hassan Hamza Zaidi \\ Economics Teacher, IB DPIMYP
}

\begin{abstract}
Akhuwat Foundation is the leading microfinance institution in Pakistan which provides interest free loans for small businesses to the poorest people of society. Since its launch in 2001, it has disbursed a sum of $\$ 110$ million to 1.9 million families without any collateral and with a recovery rate of $99.93 \%$. Such a remarkable achievements by a nonprofit organization makes it a leading interest free (Qarze e Hasna) institution in the world. This study attempts to find the impact of Akhuwat Foundation's microfinance on socio-economic conditions of the borrowers. Based on primary data collected from old and new borrowers, the study analyzes the impact of microfinance on wellbeing of the borrowers' households in terms of their housing conditions, food security, children's education, poverty status, monthly income and expenditures of the borrowers before and after the loan with the help "with or without approach". Moreover, a non-parametric approach is used to test the difference between old and new borrowers in terms of their consumption expenditure, income, poverty status, housing improvement, access to education, and access to medical facilities. Our results show that Akhuwat's loans have significantly improved the conditions of the borrowers in terms of their monthly income, expenditures, access to education/ health, and household assets. The impact was much larger for old borrowers than new borrowers. In the end we concluded that Akhuwat's non-traditional approach of lending to the poor and its model of mutual brotherhood between lenders and borrowers presents great lessons to bring positive change in the society.
\end{abstract}

Keywords: microfinance, Pakistan, poverty

\section{Introduction}

Microfinance ${ }^{1}$ structure has been designed to have an aim of giving low income people an easy access to socio-economic services. It gives them an opportunity to get self-employed and bring themselves out of poverty. Microfinance is an important tool to brawl poverty. The institutions of micro-credit are well organized and recognized all around the globe (Latifee, 2003)

The initiation of programs based on micro-credit and Grameen Bank ${ }^{2}$ which has created distinctiveness and a new meaning in today's literature of development. Now, it's a movement which has taken place all around the world. According to the Micro-credit Summit, the total output of Micro-credit programs is 54.9 million people. In which 26.8 million are the very poor people when they initiated the plan. Muhammad Yunus ${ }^{3}$ stated that at the end of 2002, they had reached the poorest families approximately to 35 million with the help of Micro-credit Programs. Micro-credit is an important aspect towards the alleviation of poverty; it creates chances for people to be self-employed instead of waiting for it to be created. It helps in bringing the poor into income flow and releases them from the clutches of poverty. If institutions give poor the access to credit under suitable arrangement and structure, then they would overcome the poverty and in this way they could bring change not only in one's life but in overall society (Latifee, 2003)

\footnotetext{
${ }^{1}$ Muhammad Yunus is the founder of Grameen Bank, formed in 1983 with the purpose of giving small micro-loans to the poor people in Bangladesh.

${ }^{2}$ Dr Amjad Saqib is a medical graduate from King Edward Medical College. Pakistan's highest bureaucratic institution selected him as the elite civil servant of Pakistan in 1985. Throughout his career of civil services, he was recognized as a hardworking and a highly capable civil servant. He resigned from civil service in 2003 to focus on his organization Akhuwat formed in 2001 to make a difference in community.

${ }^{3}$ Non-Random Program placement in well-off regions
} 
Micro-finance is becoming an important instrument to improve the socio-economic conditions of the people and reduce poverty. Variety of micro-finance institutions are working in Pakistan, these institutions include Banks, NGO's and different organizations. Akhuwat Foundation is an example of these institutions; Akhuwat Foundation is established in 2001 by Dr. Amjad Saqib ${ }^{1}$, it is basically working on poverty alleviation by giving interest free loans to the poor to improve their lives economically and socially. It uses mosque/branch office and church to give introduction to the program and credit cheques because it enhances the moral responsibility of the borrowers to return the loan on time. People interested in getting loans come to their branch offices and submit an application. The unit manager checks the applications to see whether the applicant is applicable for the loan or not i.e. is not engaged in any illegal business, lives below the poverty line and has a reliable social investment. When the application is approved by the unit manager, it is forwarded to the branch manager for assessing its technical selection. Then the case is forwarded to loan approval committee comprising of (unit, branch and area managers). This whole process takes 3 weeks, after which disbursement is done. Every borrower is bound to provide two guarantors who give assurance for timely return of loan and monitor the borrowers. If any borrower wants to start a business then the business idea is evaluated to check whether it can give more income than the household expenses so it can be repaid easily. Loan disbursement is done 2-3 times a month in which approximately 150 loaners are given the cheques and it is necessary for every borrower to be accompanied by one guarantor. The repayment of the loan has to be paid by the $7^{\text {th }}$ of every month; if it gets late then after $10^{\text {th }}$ of that month the unit manager visits the client to give a reminder. Akhuwat Foundation has 29 branches in Lahore working in specific geographical localities. The objective of Akhuwat Foundation is to provide interest free loans to the poor families enabling them to become self reliant. It also provides social guidance, capacity building and entrepreneurial training. Akhuwat Foundation gives 7 different loans to the people which include family enterprise loan, liberation loan, marriage loan, health loan, housing loan, education and emergency loans. At present until 31 May, 2015 total benefiting families are 894,376; total loans distributed to males are 538,750 and females are 355,626 with 99.9 percentage recovery. Akhuwat has 355 branches in the 210 cities and towns of the country. Akhuwat is a unique microfinance model which has been replicated by many institutions but it remains the largest such institution with the disbursed amount of $\$ 110$ million. This research studies the impact of Microfinance on socio-economic conditions of the borrowers and inquires about the role of Akhuwat Foundation as a case study.

\section{Research Question}

How microfinance provided by Akhuwat Foundation impacts the socio economic conditions (living standards, education of children, poverty alleviation) of borrowers?

\section{Objective of the Study}

The main objective of the study is to analyze the impacts of microfinance on socio-economic conditions of the borrowers.

\section{Specific Objective.}

- To see the difference between old borrowers and new borrowers in terms of their consumption expenditures, income, food, housing improvement, access to education and medical facilities.

\section{Literature Review}

In the last few decades, microfinance has become a popular tool in reducing poverty, particularly after the successful impact of Grameen Bank in Bangladesh. In Yunus (2004) it is concluded that members of the Grameen Bank got improved in their socio-economic conditions like better housing, increased income, better diet conditions with improved nutrition, women empowerment, participation of women in socio-political activities, lesser birthrate and child mortality, improved health, better access to education and consumption on clothing.

There are several ways that have been made to measure the impact of microcredit on poverty reduction, but there is little solid observed data on this issue. One key difficulty in investigating the impact of microcredit is how to assess its contribution to reduce poverty.

\footnotetext{
1 Propensity score matching (PSM) constructs a statistical comparison group by using observed characteristics, that group is based on a model of the probability of participating in the treatment. The propensity score of the members are matched to non-members. Then the mean difference in outcomes of the groups helps in calculating the average treatment effect of the program.
} 


\section{Non-Randomized Approaches}

Quite a few studies measure the impact of microcredit by comparing the borrowers of microfinance with a group of people who have no access to microfinance, and that group is known as control group. In majority of the cases, these researches use non-randomized approaches. Initially, changes in the socio-economic conditions of the borrowers of microcredit may not be outcome of microcredit. It is eminent that comparatively rich people have less inclination towards risk as compared to the poor people. This could possibly persuade rich people to apply for microcredit rather than poor people, that is, it creates self selection bias. An ex-post evaluation of income of the groups (rich and poor) in this condition may guide to the wrong conclusion that microcredit has enthused income. Secondly, in order to increase the chances of microcredit to flourish, Microfinance institutions have to decide to expand their activities in reasonably more well-off regions. ${ }^{1}$ Evidently, this biases any association between the borrowers of microcredit and the control group (Armenda'riz de Aghion \& Morduch, 2005; Karlan, 2001).

The non-randomized approaches used in microcredit studies to measure their impact assessment show diverse evidence. Pitt and Khandker (1998) did a significant study on the impact of microcredit in Bangladesh. They used the survey data of household from 1991- 92 and found that microcredit increases the borrower's consumption expenditure, particularly if women take loans. Khandker (2005) using the panel data for 1991-92 and 1999, examines that the benefit from microcredit is more for the extremely poor borrowers rather than the fairly poor borrowers. Chemin (2008) in his study examines the impact of microfinance and for that used the Bangladesh surveys and propensity score matching ${ }^{2}$ technique was applied. Findings of his study revealed that access to microcredit positively impact the child enrollment in schools, expenditures and labor supply.

Copestake et al, (2005) did a study to see the impact of microcredit by using the survey data in association with a rural community banking program but are less confident about its impact. In Peru 2002, Promuc used two different evaluation methods to find the impact of microcredit, these evaluation methods were qualitative in-detail interviews and the difference in difference (DID) approach ${ }^{3}$. The findings were that instead of the core poor, it is the more well off poor who take advantage from the microcredit institutions.

\section{Randomized Approaches}

Lately, microcredit studies have shifted to randomized approaches due to some flaws in the methods of non-randomized approaches. These microcredit studies use two groups that are control group ${ }^{4}$ and target group ${ }^{5}$. Results from the randomized approaches studies are mixed; they suggest stronger outcomes for groups that are not usually targeted by microcredit institutions. Randomized approach is used by Coleman $(1999,2006)$ one of the first researcher to use this approach to evaluate the impact of microcredit. In this study he used an event, that is, an introduction of microcredit in the Northeastern part of Thailand with unexpected delays by the microfinance program. His analysis was based on the quasiexperimental setting, it showed that microcredit has assenting impact on only well off villagers. Karlan and Zinman (2009) in Manila, Philippines studied the impact of microfinance on small business investment. Their results showed a dispersed picture but an important result was increased profits from small business especially for higher-income capitalist and males. They also found out some prominent results which showed that small businesses replace formal insurance into informal insurance and labor into education. Banerjee et al, (2009) assessed the impact of opening of branches of MFl's in Hyderabad's slums and out of 104 slums, at random half were selected for opening a new branch. Results showed the impact of introducing microcredit to be very reasonable.

Randomized approaches and their use has been criticized (Deaton, 2009; Rodrik, 2008). Criticism lifted the fact that one microcredit experiment's result cannot be universalized. For example, if a microcredit program works in some particular city at some point in time, that doesn't mean it will work in the same way elsewhere. The supporters of randomized approaches

\footnotetext{
${ }^{1}$ Difference in Difference technique is used to differentiate between income and other variables of interest for the borrowers and nonborrowers in target locales and with the difference in income and other variables of interest in control locales

${ }^{2}$ Control group doesn't have access to microcredit and they are known as non borrowers.

3 Target group has access to microcredit and they are known as the borrowers.

4 Tsunami in Srilanka in 2004

5 One group was consisted of the borrowers who were affected by the tsunami disaster and the other group was consisted of the borrowers who were not affected by the tsunami disaster.
} 
give answer to this dilemma, which is to repeat the experiments to see whether they work in different context. It is uncertain that after how many times it is safe to conclude that experiment works. Additionally, to run the experiments again and again are time consuming and costly and incentive for researchers is also missing. Easterly (2009), Rodrik (2008), Roodman and Morduch (2009) conclude, both randomized and non-randomized approaches are useful to examine the impact of microfinance and these approaches have strengths and weaknesses.

Becchetti and Castriota (2011) examine the impact and effectiveness of microcredit as recuperation after a natural disaster. Researchers evaluated the impact of microcredit loans in serving people who were affected by the disaster. ${ }^{1}$ To examine the impact of microcredit on the well-being of people, researchers used quasi-natural experiment which created two randomly chosen groups. ${ }^{2}$ Data of 305 randomly chosen microcredit borrowers was collected. Becchetti and Castriota explained that before the disaster there was convergence in income of the borrowers due to microcredit loans. However, the process of convergence in income was disrupted due to the disaster, but microcredit loans were helpful in narrowing down the income gap between the borrowers who got affected and who were not. Microcredit loans positively contributed in the convergence of real income but it was not observed for donations, governmental subsidies and grants. This study reveals that there is a strong proof for the usefulness of microcredit as a recovery tool and this is a very comprehensive study on the role of microcredit in post-disaster conditions.

A new methodology has been introduced by McIntosh, Villaran, and Wydick (2011) in their study to see the impact of microcredit on the welfare of the borrowers. The methodology was Retrospective analysis of Primary Events ${ }^{3}$ nearby to treatment. This technique assesses the changes in the household's welfare due to a treatment i.e. access to microcredit; treatment is based upon a cross-sectional study consisting of questions related to primary events in the history of the borrowers. To evaluate the impact of a treatment, the researchers can make a retrospective panel data set by using the relative questions in context of those events. The researchers applied this methodology by using survey questionnaires among 218 Guatemalan households that obtained microcredit loans in different times. They examined the effects of microcredit on dwelling expansion. The results of the analysis showed the boosts in the probability of dwelling expansion but these outcomes were rather modest. Researchers can utilize this new methodology to see the impact of microcredit, since it does not require costly and lengthy multiple cross-sectional studies, used in impact studies.

\section{Research Methodology}

\section{Unit of Assessment and Tools of Study}

In this study household is used as a unit of assessment and data is collected with the help of structured questionnaire and this study has a cross-sectional design. Household is the most common unit of assessment.

\section{Survey Method}

In this research old borrowers are compared with the new borrowers. The old borrowers with two or more than two years experience with the Akhuwat Foundation are treated as a treatment group, while the new borrowers are treated as a control group. The comparison of the old and new borrower's helps to control the selection bias; underlying principle is that these two groups will not differ in their entrepreneurial spirit.

\section{Cluster Sampling and Systematic Sampling}

Akhuwat Foundation has 29 branches in Lahore which are geographically dispersed, so this research is using cluster sampling and systematic sampling. Cluster is formed on the basis of old and new Lahore. Data is collected from 13 branches of Akhuwat Foundation and from every branch every $5^{\text {th }}$ member is been selected from the register on the basis of systematic sampling. The implication of this technique counters any chance of bias in the samples to a significant level.

\section{Sample Size}

\footnotetext{
${ }^{1}$ Any event in the history of household's life that is memorable, discrete and vital to their welfare.

2 This approach is heavily derived from (Shirazi \& Khan, 2009)

3 J. Thomai, Leksikologjia e gjuhës shqipe, Tiranë, 2006, p. 332
} 
This research has a sample size of 105 borrowers from 13 branches out of 29 branches of Akhuwat Foundation in Lahore. Cross-sectional study with two groups of borrowers, with a sample size of 60 for old borrowers and 45 for new borrowers is been used in this research.

\section{With or Without Approach}

This model helps us to find the net impact of microfinance on the alleviation of poverty, income, expenditures and assets. ${ }^{1}$.

$P^{*}=\left(\mathrm{Pb}_{1}-\mathrm{Pb}_{0}\right)-\left(\mathrm{Pnb}_{1}-\mathrm{Pnb}_{0}\right)$

Where,

$\mathrm{P}^{*}$ represents the net impact of microfinance on the poverty condition of borrower households. $\mathrm{Pb}_{1}$ represents the poverty condition of the old borrower households after taking the loan and $\mathrm{Pbo}$ represents the poverty condition of the borrowers before taking the loan. Pnb1 shows the poverty condition of the new borrower households after taking the loan and Pnbo shows the poverty condition of the new borrowers before taking the loan.

\section{Descriptive Analysis of Data}

\section{Economic Impact of Microfinance on the Borrowers}

\section{Targeting of the microfinance and its Impact on Borrowers}

This section studies the objective of the microfinance and its impact on the borrowers. For this purpose samples of old borrowers (target group) and new borrowers (control group) have been taken into account and decomposed into the categories of poor and non-poor by using the poverty lines.

\section{Table 1: Poverty Status of the Old Borrowers Before and After Loan}

\begin{tabular}{|c|c|c|c|c|c|}
\hline & \multicolumn{2}{|c|}{$\begin{array}{l}\text { Poverty Line } \\
\text { Rs(3150 per HH) }\end{array}$} & \multicolumn{2}{|l|}{$\begin{array}{l}\text { Poverty Line } \\
\text { Rs(3150 per HH) }\end{array}$} & T1 \\
\hline & $\begin{array}{l}\text { Old Borrowe } \\
\text { (Before Loar }\end{array}$ & & $\begin{array}{l}\text { Old Borrowers } \\
\text { (After Loan) }\end{array}$ & & \% Difference \\
\hline Status & $\begin{array}{l}\text { Households } \\
(\mathrm{HH})\end{array}$ & $\%$ of $\mathrm{HH}$ & $\begin{array}{l}\text { Households } \\
(\mathrm{HH})\end{array}$ & $\%$ of $\mathrm{HH}$ & \\
\hline Poor & 49 & 81.7 & 22 & 36.7 & -45 \\
\hline Non Poor & 11 & 18.3 & 38 & 63.3 & 45 \\
\hline Total & 60 & 100 & 60 & 100 & \\
\hline
\end{tabular}

The above table shows that $81.7 \%$ of the old borrowers were poor before taking the loan and $18.7 \%$ were non-poor. While, on the other hand $36.7 \%$ of the old borrowers are found to be poor after taking the loan and $63.3 \%$ are found to be nonpoor. The main objective of Akhuwat Foundation is to get the poor out of poverty by giving them small loans through their microfinance program. However, microfinance loans from Akhuwat Foundation have reduced the number of poor households by $45 \%$ (i.e from $81.7 \%$ to $36.7 \%$ ) and they shifted to non-poor status. The results support the major objective of the Akhuwat Foundation as the number of non-poor has increased by $45 \%$ (i.e from $18.3 \%$ to $63.3 \%$ ).

Table 2: Poverty Status of the New Borrowers Before and After Loan



${ }^{1}$ H. J. Franz, Lexikographie, Königstein, 1985, p. 369 


\begin{tabular}{|llllll|}
\hline Status & $\begin{array}{l}\text { Households } \\
(\mathrm{HH})\end{array}$ & $\%$ of $\mathrm{HH}$ & $\begin{array}{l}\text { Households } \\
(\mathrm{HH})\end{array}$ & $\%$ of $\mathrm{HH}$ \\
\hline Poor & 30 & 66.7 & 20 & 44.4 & 22.3 \\
\hline Non Poor & 15 & 33.3 & 25 & 55.6 & 100 \\
\hline Total & 45 & 100 & 45 & & 22.3 \\
\hline
\end{tabular}

The above table shows that $66.7 \%$ of the new borrowers were poor before taking the loan and $33.3 \%$ were non-poor. While, on the other hand after taking the loan poor households have decreased from $66.7 \%$ to $44.4 \%$ and non-poor households have increased from $33.6 \%$ to $55.6 \%$. The main objective of Akhuwat Foundation is to get the poor out of poverty by giving them small loans through their microfinance program. However, microfinance loans from Akhuwat Foundation have reduced the number of poor households by $22.3 \%$ (i.e from $66.7 \%$ to $44.4 \%$ ) and they shifted to non-poor status. The results support the major objective of the Akhuwat Foundation as the number of non-poor has increased by $22.3 \%$ (i.e from $33.3 \%$ to $55.6 \%$ ).

Table 3: Net Impact of Akhuwat Microfinance Program on Poverty Status of the Borrowers

\begin{tabular}{|llll|}
\hline Status & Last Column of Table 4.9 (T1) & Last Column of Table 4.10 (T2) & Difference \\
\hline Poor & -45 & -22.3 & -22.7 \\
\hline Non-Poor & 45 & 22.3 & 22.7 \\
\hline
\end{tabular}

The result of the above table shows the net impact of Akhuwat microfinance program on poverty status of the old and new borrowers. This table is created by taking difference of the last column of table 4.9 (T1) and last column of table 4.10 (T2). The difference of the difference in the last column of the above table reveals that microfinance has overall decreased the poverty about $22.7 \%$

\section{Impact on Households Income}

The table below shows the impact of microfinance on borrower's income. It shows the difference in the average income of the old borrowers (poor and non-poor) and the new borrowers (poor and non-poor).

Table 4: Difference in Average Income of the Old and New Borrowers

\begin{tabular}{|lllllllll|}
\hline \multicolumn{2}{l}{ Old Borrowers (Target Group) } & \multicolumn{2}{ll}{ New Borrowers (Control Group) } & \% Diff of the Diff \\
\hline Mean & Before Loan & After Loan & \%Diff & $\begin{array}{l}\text { Before } \\
\text { Loan }\end{array}$ & After Loan & \%Diff & \\
\hline Poor & 12644.90 & 15409.09 & 21.86 & 12616.67 & 15250 & 20.87 & 0.99 & \\
\hline Non-Poor & 25681.82 & 28631.58 & 11.48 & 28700 & 30160 & 5.09 & 6.39 \\
\hline
\end{tabular}

The above table shows that the income of the poor old borrowers has increased by $21.86 \%$. While, the income of the nonpoor old borrowers has increased by $11.48 \%$. Similarly, the income of the poor new borrowers has increased by $20.87 \%$ and income of the non-poor new borrowers has increased by $5.09 \%$. The last column shows the net impact of microfinance on income of the poor old and new borrowers, which is about $1 \%(0.99 \%)$ and shows very marginal increase. However, the net impact of microfinance on income of the non-poor old and new borrowers is about $6.4 \%$.

\section{Impact on Households Assets}

At the household level, one of the prominent indicators of microfinance intrusion is the change in household's asset ownership. It also indicates the improvement in households' wealth. Assuming the fact that intervention of microfinance in household's lives increases their income and their capacity to have more assets. 
Table 5: Household Assets and Change in Asset of All Borrowers

\begin{tabular}{|llll|}
\hline Item & Before Loan & After Loan & Percentage Change \\
\hline Motorcycle & $70.5 \%$ & $82.9 \%$ & $12.4 \%$ \\
\hline Livestock & $0 \%$ & $1 \%$ & $1 \%$ \\
\hline Washing Machine & $79 \%$ & $85.7 \%$ & $6.7 \%$ \\
\hline Refrigerator & $77.1 \%$ & $82.9 \%$ & $5.8 \%$ \\
\hline Sewing Machine & $78.1 \%$ & $84.8 \%$ & $6.7 \%$ \\
\hline TV & $89.5 \%$ & $94.3 \%$ & $4.8 \%$ \\
\hline Fans & $100 \%$ & $100 \%$ & $0 \%$ \\
\hline Air Cooler & $8.6 \%$ & $9.5 \%$ & $0.9 \%$ \\
\hline Air Conditioner & $8.6 \%$ & $8.6 \%$ & $0 \%$ \\
\hline
\end{tabular}

Table shows the ownership of the assets before and after the intervention of microfinance. The above table reveals that more than $70 \%$ of the households had assets like motorcycle, washing machine, refrigerator, sewing machine, TV, and fans before taking the loan. Less than $10 \%$ of the households had assets like air cooler and air conditioner before taking the loan. Some of the common assets before taking the loan were washing machine and sewing machine $(79 \%, 78.1 \%)$, TV $(89.5 \%)$, motorcycle $(70.5 \%)$ and refrigerator $(77.1 \%)$, while the few households had air cooler $(8.6 \%)$, air conditioner (8.6\%). The survey results show that ownership of the assets by households has increased after taking loan from Akhuwat Foundation. Ownership of motorcycle, washing machine, refrigerator, sewing machine, TV, and air cooler increased from $70.5 \%$ to $82.9 \%, 79 \%$ to $85.7 \%, 77.1 \%$ to $82.9 \%, 78.1 \%$ to $84.8 \%, 89.5 \%$ to $94.3 \%$ and $8.6 \%$ to $9.5 \%$.

The last column shows the percentage change the assets and it shows that there is a positive growth in the assets of the borrowers. There is a positive growth in assets like (motorcycle, livestock, washing machine, refrigerator, sewing machine, TV and air cooler) except for fan and air conditioner. Thus, it shows that microfinance intervention by Akhuwat Foundation has a positive impact on the household's asset ownership.

Table 6: Change in Assets of Old and New Borrowers

\begin{tabular}{|c|c|c|c|c|c|c|c|}
\hline \multirow[t]{2}{*}{ Item } & \multicolumn{3}{|c|}{$\begin{array}{l}\text { Old Borrowers } \\
N=60\end{array}$} & \multicolumn{3}{|c|}{$\begin{array}{l}\text { New Borrowers } \\
N=45\end{array}$} & \multirow[t]{2}{*}{ Percentage Diff of Diff } \\
\hline & $\begin{array}{l}\text { Before } \\
\text { Loan }\end{array}$ & After Loan & $\%$ Change & $\begin{array}{l}\text { Before } \\
\text { Loan }\end{array}$ & After Loan & $\%$ Change & \\
\hline Motorcycle & $60 \%$ & $81.7 \%$ & $21.7 \%$ & $84.4 \%$ & $84.4 \%$ & $0 \%$ & $21.7 \%$ \\
\hline Livestock & $0 \%$ & $1.7 \%$ & $1.7 \%$ & $0 \%$ & $0 \%$ & $0 \%$ & $1.7 \%$ \\
\hline $\begin{array}{l}\text { Washing } \\
\text { Machine }\end{array}$ & $75 \%$ & $86.7 \%$ & $11.7 \%$ & $84.4 \%$ & $84.4 \%$ & $0 \%$ & $11.7 \%$ \\
\hline Refrigerator & $70 \%$ & $80 \%$ & $10 \%$ & $86.7 \%$ & $86.7 \%$ & $0 \%$ & $10 \%$ \\
\hline Sewing Machine & $81.7 \%$ & $86.7 \%$ & $5 \%$ & $73.3 \%$ & $82.2 \%$ & $8.9 \%$ & $-3.9 \%$ \\
\hline TV & $85 \%$ & $93.3 \%$ & $8.3 \%$ & $95.6 \%$ & $95.6 \%$ & $0 \%$ & $8.3 \%$ \\
\hline Fans & $100 \%$ & $100 \%$ & $0 \%$ & $100 \%$ & $100 \%$ & $0 \%$ & $0 \%$ \\
\hline Air Cooler & $8.3 \%$ & $10 \%$ & $1.7 \%$ & $8.9 \%$ & $8.9 \%$ & $0 \%$ & $1.7 \%$ \\
\hline
\end{tabular}




\begin{tabular}{|llllllll|}
\hline Air Conditioner & $3.3 \%$ & $3.3 \%$ & $0 \%$ & $15.6 \%$ & $15.6 \%$ & $0 \%$ & $0 \%$ \\
\hline
\end{tabular}

The above table shows the percentage change in the possession of the assets by the old and new borrowers. The percentage change table shows the positive change in the growth of the assets of the old borrowers, while on the other hand it doesn't show any percentage change in the assets of the new borrowers. However, the last column shows the net impact of the microfinance on the growth of assets of the old and new borrowers. It shows the positive net impact of microfinance on the growth of assets of the borrowers except for sewing machine. The above results show that microfinance does help in increasing the assets of the borrowers.

\section{Impact on Household's Consumption Expenditures}

The table below shows the impact of microfinance on borrower's consumption expenditures. It shows the difference in the average monthly consumption expenditures of the old borrowers (poor and non-poor) and the new borrowers (poor and non-poor).

Table 7: Difference in Average Consumption of the Old Borrowers and New Borrowers

\begin{tabular}{|lllllll|l|}
\hline & \multicolumn{3}{c}{ Old Borrowers (Target Group) } & \multicolumn{3}{c|}{ New Borrowers (Control Group) } & \% Diff of the Diff \\
\hline Mean & Before Loan & After Loan & \%Diff & Before Loan & After Loan & \%Diff & \\
\hline Poor & 11683.673 & 15568.182 & 33.25 & 13583.333 & 14875.000 & 9.51 & 23.74 \\
\hline Non-Poor & 17045.454 & 18684.210 & 9.61 & 19333.333 & 18200.000 & -5.86 & 15.47 \\
\hline
\end{tabular}

The above table shows that the average monthly consumption expenditures of the poor old borrowers have increased by $33.25 \%$. While, the average monthly consumption expenditures of the non-poor old borrowers have increased by $9.61 \%$. Similarly, the average monthly consumption expenditures of the poor new borrowers have increased by $9.51 \%$ and average monthly consumption expenditures income of the non-poor new borrowers has decreased by $-5.86 \%$. The reason behind this decrease is that number of non-poor new borrowers has reduced after the loan so that is why their average consumption expenditures also reduced after loan. The last column shows the net impact of microfinance on average monthly consumption expenditures of the old and new borrowers, the net average monthly consumption expenditures of the poor old and new borrowers is about $23.74 \%$ and shows very significant increase. However, the net impact of microfinance on average monthly consumption expenditures of the non-poor old and new borrowers is about $15.47 \%$.

\section{Conclusion}

The impact of microfinance on socio-economic conditions of the borrowers has been investigated in this study. This study attempted to find the impact of microfinance services by Akhuwat Foundation on household's living standard. This study has used 'with or without' approach. The important results of the study are as follows.

- The results of the study show that Akhuwat Microfinance Program has increased the income of the poor old and new borrowers by $21.86 \%$, and $20.87 \%$; and the income of the non-poor old and new borrowers by $11.48 \%$, and $5.09 \%$ respectively.

- Akhuwat Microfinance Program has increased the average monthly consumption expenditures of the poor old and new borrowers by $33.25 \%$, and $9.51 \%$; and average monthly consumption expenditures of the non-poor old by $9.61 \%$. It decreased the average consumption expenditures of the non-poor new borrowers by $5.86 \%$.

\section{Limitations and Future Prospects}

- The study could not use longitudinal data.

- At one or two places, presence of Akhuwat Foundation representative was necessary, which could make opinions biased.

- This study has collected data from the branches of Akhuwat Foundation based in Lahore due to lack of resources. Future researchers can extend the work on Akhuwat Foundation by taking sample from all major cities of Pakistan. 
- A comparative study could be done by taking into account the role of other microfinance institutions in Pakistan as well.

\section{Policy Recommendations}

The results of the study show that microfinance has a positive impact on socio-economic conditions of the borrowers. There are some recommended policies measures that can be considered.

- Government should give their support to other microfinance institutions in Pakistan to give interest free loans like Akhuwat Foundation.

- There were few dissatisfactions regarding group loaning, Akhuwat Foundation should give due attention and listen to their recommendations.

- There is a dire need of more microfinance institutions in Pakistan to eradicate poverty and improve socio-economic condition of the people. Government of Pakistan should pay attention towards it.

\section{References}

[1] Armenda'riz De Aghion, B., \& Morduch, J. (2005). The economics of microfinance. Cambridge, MA: MIT Press.

[2] Banerjee, A., Duflo, E., Glennerster, R., \& Kinnan, C. (2009). The miracle of microfinance? Evidence from a randomized evaluation. Unpublished paper, Abdul Latif Jameel Poverty Action Lab and MIT.

[3] Becchetti, L., \& Castriota, S. (2011). Post Tsunami intervention and the socioeconomic well-being of microfinance borrowers. World Development, 39(6), 898-912.

[4] Chemin, M. (2008). The benefits and costs of microfinance: Evidence from Bangladesh. Journal of Development Studies, 44(4), 463-484.

[5] Coleman, B. E. (1999). The impact of group lending in Northeast Thailand. Journal of Development Economics, 60(1), 105-141.

[6] Copestake, J., Dawson, P., Fanning, J. P., McKay, A., \& Wright- Revolledo, K. (2005). Monitoring the diversity of the poverty outreach and impact of microfinance: A comparison of methods using data from Peru. Development Policy Review, 23(6), 703-723.

[7] Deaton, A. (2009). Randomization in the tropics, and the research for the elusive keys to economic development. Unpublished paper, Center for Health and Wellbeing, Princeton University.

[8] Easterly, W. (2009). Development experiments: Ethical? Feasible? Useful? http://blogs.nyu.edu/fas/dri/aidwatch/2009/07/development_experiments_June 16.

[9] Karlan, D., \& Zinman, J. (2009). Expanding microenterprise credit access: Using randomized supply decisions to estimate the impacts in Manila. Unpublished paper, Innovations for Poverty Action.

[10] Karlan, D. (2001). Microfinance impact assessments: The perils of using new members as a control group. Journal of Microfinance, 3(2), 75-85.

[11] Khandker, S. R. (2005). Microfinance and poverty: Evidence using panel data from Bangladesh. The World Bank Economic Review, 19(2), 263-286.

[12] Latifee, H. I. (2003). Micro-credit and Poverty Reduction. Presented at the International Conference on "Poverty Reduction through Microcredit", 11.

[13] McIntosh, C., Villaran, G., \& Wydick, B. (2011). Microfinance and home improvement: Using retrospective panel data to measure program effects on discrete events. World Development, 39(6), 922-937.

[14] Pitt, M. M., \& Khandker, S. R. (1998). The impact of group-based credit programs on poor households in Bangladesh: Does the gender of participants matter? Journal of Political Economy, 106(5), 958-996.

[15] Rodrik, D. (2008). The new development economics: We shall experiment, but how shall we learn? Unpublished paper, John F. Kennedy School of Government, Harvard University.

[16] Roodman, D., \& Morduch, J. (2009). The impact of microcredit on the poor in Bangladesh: Revisiting the evidence. Working paper 174, Washington, DC: Center for Global Development.

[17] Shirazi, N. S., Khan, A. U. (2009), Role of Pakistan Poverty Alleviation Fund's Micro Credit in Poverty Alleviation. Pakistan Esconomic and Social Review, Volume 47, No. 2 (Winter 2009), pp. 215-228. 
[18] Younus, M. (2004), "Expanding microcredit Outreach to Reach the Millennium Development Goals: Some Issues for Attention". In Attacking Poverty with Microcredit, Ed. Salehuddin Ahmed and M.A. Hakim the University Press Ltd. Dhaka, Bangladesh. 